\title{
Ivanytska Svetlana
}

$\mathrm{PhD}$, Associate professor

Department of Economics, Entrepreneurship and Marketing National University «Yuri Kondratyuk Poltava Polytechnic»

Poltava, Ukraine

ORCID 0000-0002-7111-270X

Ageicheva Anna

$\mathrm{PhD}$, Associate Professor

General Linguistics and Foreign Languages Department

National University «Yuri Kondratyuk Poltava Polytechnic»

Poltava, Ukraine

ORCID 0000-0002-0140-9604

Halaida Tetiana

Senior lecturer

Department of Economics, Entrepreneurship and Marketing

National University «Yuri Kondratyuk Poltava Polytechnic»

Poltava, Ukraine

ORCID 0000-0003-2747-7135

\section{ENERGY-EFFICIENT CHANGES MOTIVATIONAL MECHANISMS FORMATION METHODOLOGICAL ASPECTS AT THE ENTERPRISE}

Improving energy efficiency can quickly reduce the cost and resource intensity of production by maximizing the use of available energy sources and related material assets. This, in turn, will reduce not only costs, but also the volume of energy consumption. The transition to an energy-efficient economy requires optimization of the energy consumption system, but not every employee is interested in the activities carried out by enterprises for this purpose.

Existing motivational mechanisms do not sufficiently contribute to improving the energy efficiency of enterprises in Ukraine, and in general to the consumer attitude to energy resources, not only in everyday life, but also in the workplace. Any changes are often perceived negatively, especially those that require the development of new mental rules and skills. Energy-efficient measures cannot immediately become popular. It is necessary to form an appropriate attitude to them among the staff.

Motivating the staff of each business entity in Ukraine to implement energy-efficient changes is a significant reserve for saving material resources, optimizing costs and increasing the level of production efficiency.

Therefore, carrying out relevant research to develop scientific and methodological foundations for effective motivational mechanisms formation for the introduction of energy-efficient changes in Ukrainian enterprises is relevant in the development of an energy-efficient economy. 
Theoretical and practical aspects of employee's motivation at enterprises of various types of economic activity in Ukraine to introduction of energy-efficient measures were considered in scientific paper by many scientists: Vasyuta V. B. [1], Grabar O. I. [2], Danilkova A. Yu. [3], Zalashchuk L. V. [4], Klimchuk M. M. [5], Kotelnikova Yu. M. [7], Sotnik I. M. [8], Kasyanova D. Yu. [10], Nakonechnaya L. Yu. [11], Temchenko G. V. [13] and others.

However, the methodological aspects of motivation the mechanism for energy-efficient changes for enterprises operating in the mining and processing industry, construction, and transport have not been sufficiently developed yet.

The lack of an effective energy efficiency management system, the introduction of changes in this process leads to significant energy costs for production and low investment attractiveness of energy-intensive enterprises.

The main reasons for low energy efficiency at enterprises are:

- significant physical and moral deterioration of fixed assets and, as a result, high accident rate of equipment;

- low level of control and regulation of energy consumption;

- increased losses in production processes and high consumption of primary fuel and energy resources;

- lack of qualified specialists in the field of energy management;

- low level of staff motivation to energy saving, etc. [10].

Adapting to a new vision of motivating employees problem and the business itself in energy-efficient changes may be of interest to those who want to optimize their processes of energy consumption, constantly improve economic efficiency, reduce the risks of accidents and emergencies through failures in energy supply, and encourage staff to implement energy-efficient projects.

For any business entity, a problematic approach to rationalizing the use of energy resources should be implemented through the main goal of the enterprise's operation to obtain profit, economic benefits from the optimal use of all resources, and energy cannot be an exception.

Economically feasible, design achievable and actually existing levels of energy efficiency are closely related to the process of energy saving at the enterprise, which necessitates a more detailed consideration of the impact of factors of energy saving and energy efficiency at the enterprise, which determines the specifics and determines energy saving features [11].

To get the maximum effect from the implementation of energy-efficient changes program at the enterprise, it must represent the optimal set of energysaving measures for it.

Two models are important to ensure the development of highly effective motivation of personnel in a particular enterprise:

1) model of employees mutual interests coordination at the enterprise;

2) model of motivation and stimulation labor organizational and economic mechanism [13]. 
The concept of the motivation model mechanism that stimulates the effectiveness of labor activity is to recognize the management of energy-efficient changes as the key to effective business activity (Fig. 1).

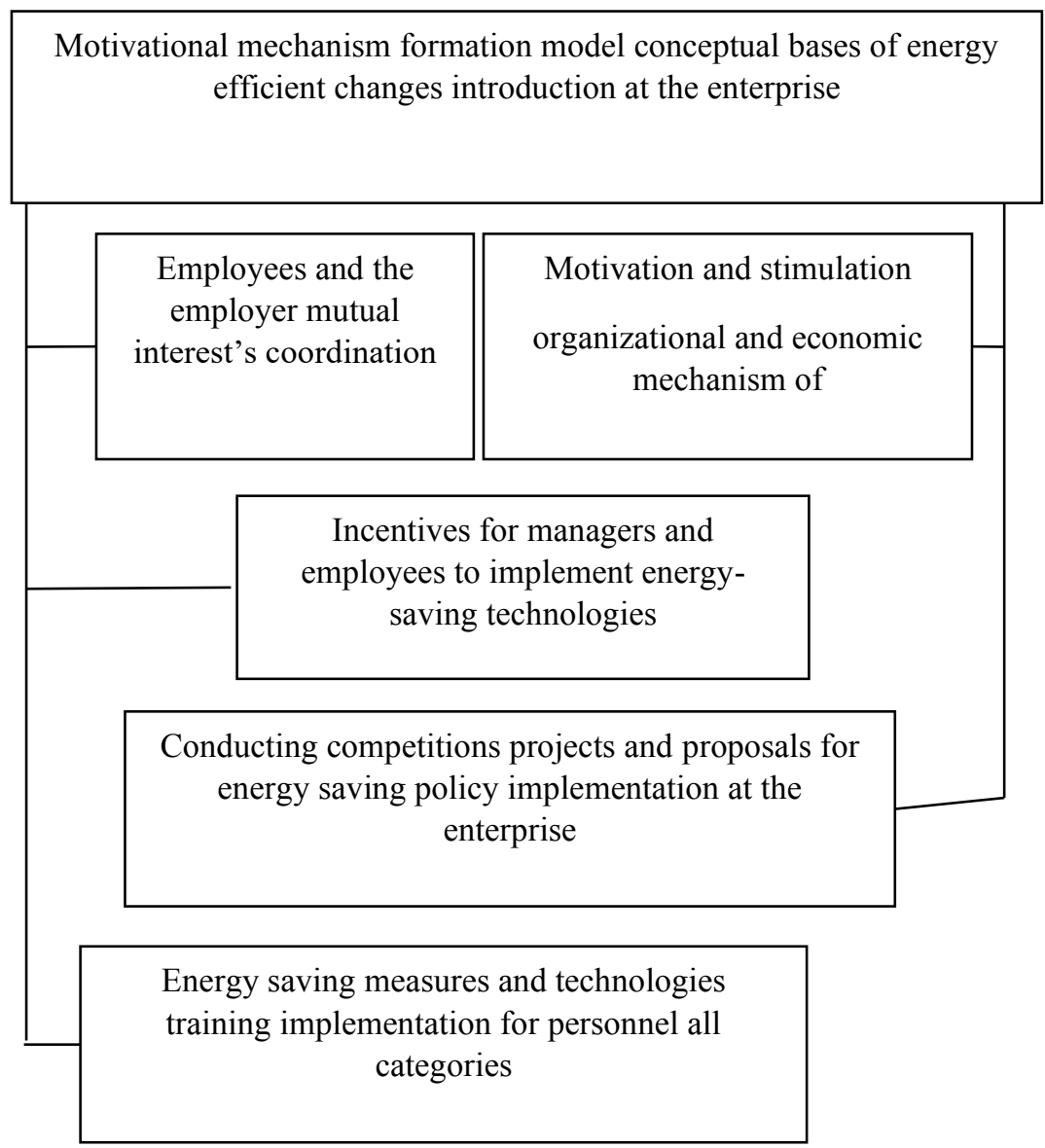

Fig. 1 - Company's personnel ensuring effective motivation model formation regarding implementation

The motives of employees that encourage them to work more effectively are different, but to a certain extent are divided into economic and socio-psychological in different proportions. Motivational monitoring can help to identify the key motivations of staff in structural units not only to implement energy-efficient changes, but also to consciously or unconsciously resist them. 
The importance of this problem actualizes the development of economic and managerial incentives mechanism based on dependence of reward entities formation from the results of energy efficiency, profit fair distribution between energy saving project participants [5].

The scientific and methodological level of motivation for energy saving includes the following postulates: axiological, ontological, epistemological [2].

This model can serve as a methodological tool for finding the optimal organization of production and labor that meets the interests of all social partners (community, employer, employees), which ultimately leads to an economic effect in the form of increased profitability, increased productivity, increased competitiveness and investment attractiveness.

Today, as well as the last decade, at the enterprises of Ukraine, except for those that have foreign partners, to assess the performance of employees mainly use the accounting of labor results and analysis of factors that affect them. The experience of Western companies display that the evaluation of results is necessary, but it is not a sufficient condition and criterion for making informed personnel decisions. No less important is the definition of business and personal qualities that are manifested in the process of work. To do this, it is proposed to use the methods of expert assessments, methods of assessment "360 degrees", CRI, integrated assessment and others, in which, in accordance with the accepted criteria, the quality characteristics of employees and their ability to achieve maximum performance, as well as the level of competence are determined. This makes it possible to use an individual approach in the selection of personnel. Based on processing the collected information about the quality characteristics and performance indicators of each employee and structural unit, managers have the opportunity to form a unique and at the same time effective motivational mechanism for a particular company and even for an individual employee.

The conditions for improving the energy efficiency of the enterprise is the availability of personnel with established energy efficiency competence in order to enable the company's staff has energy efficiency competence, the company's management must develop and maintain a staff development plan and related processes [7].

Another component of effective motivational mechanism formation should be that each employee himself should be informed about the features of the company's activities, output, energy expenditure, as well as possible options for evaluating the results of their activities.

The new economic conditions for entrepreneurial activity are closely related to the rapid changes in the external environment of enterprises, should contribute to the formation of professional competencies of personnel, which are associated with the use of resources and property of the enterprise, recognition of the need to take care of the environment and territory, protect their own interests and the interests of society. 
Energy-efficient competence formation depends on the understanding of its needs and motivational attitudes. Material incentives and non-material motivation system of employees should be based on comprehensive monitoring of employee behavior, that is, on motivational monitoring [7].

Taking into account these aspects, the motivational model, which provides employees with the following competencies for their development and improvement, is schematically shown in Fig. 2.

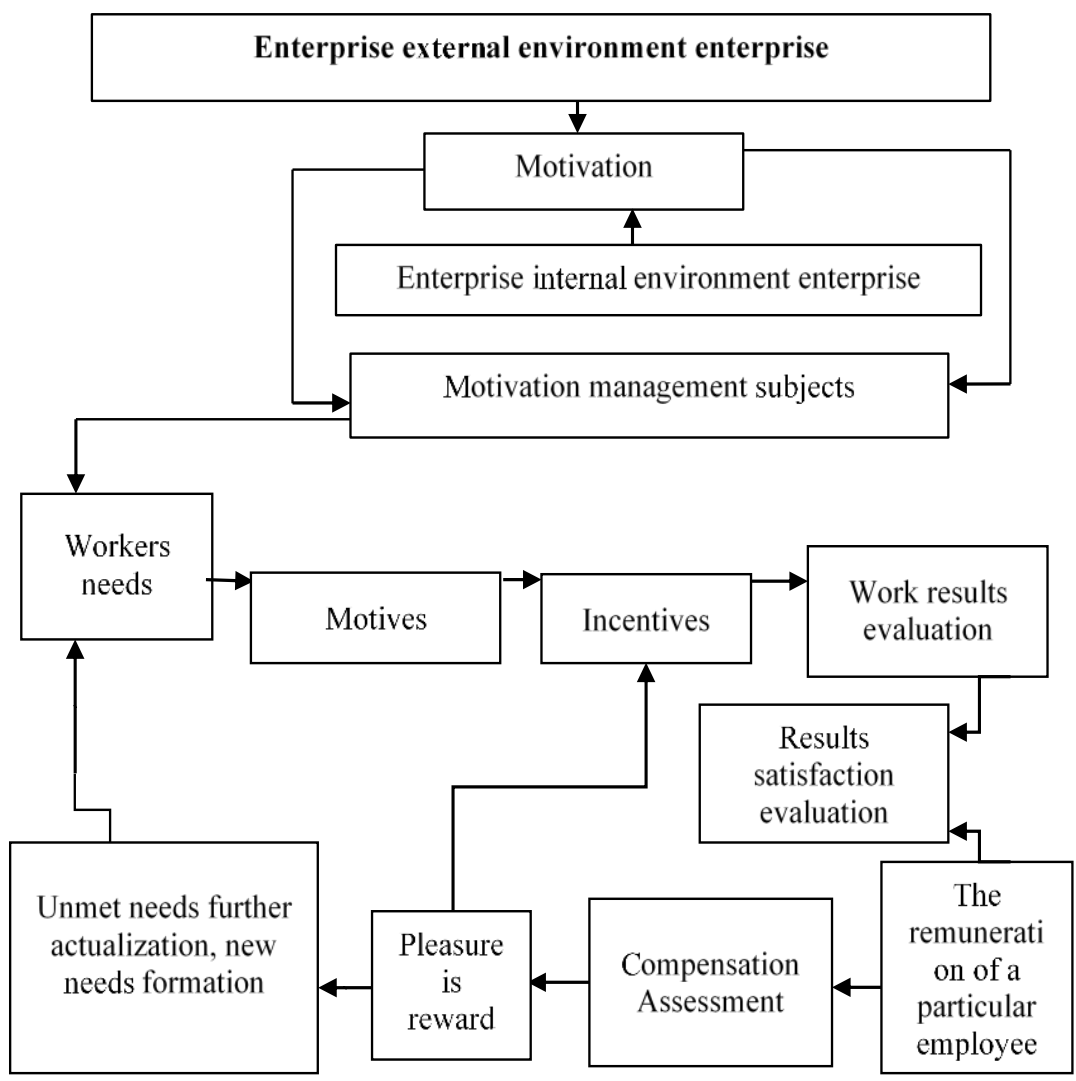

Fig. 2 - Employee motivation mechanism model for implementing energy-efficient changes

The motivation system for implementing energy efficient changes at the enterprise level in relation to an individual employee should be based on certain requirements: 
- provision of equal opportunities in relation to employment and promotion by the criterion of performance evaluation results;

- coordination of the level of remuneration with its results and recognition of personal contribution to the overall result;

- job security for employees who participate in the implementation of specific projects of energy-efficient changes;

- creating appropriate conditions to protect the health, safety and welfare of all employees;

- providing opportunities for the growth of professional skills, the implementation of the abilities of employees, providing training programs, professional development;

- maintaining an atmosphere of trust in the team, interest in the implementation of a common goal, the possibility of two-way communication between managers and subordinates.

The main non-material means of maintaining the activity of staff to ensure energy-efficient changes is the creation of favorable working conditions, persuasion, the power of example, moral encouragement. The latter are determined by the fact that incentives for energy-efficient shifts form an active environmentaloriented life position, and then an environmentally favorable climate in the collective and society as a whole. At the same time, it is important to provide a correct and justified system of moral incentives, taking into account the traditions and historical experience of the country [8].

Basic rules of motivation to ensure energy-efficient changes, compliance with which will increase the effectiveness of motivational activities:

- use of regular rewards and recognition of success and effort;

- encouragement not only for effective actions, but also for achievement of intermediate results;

- application of the principle of trust (creating a sense of freedom of action of managers, the ability to control the situation).

The following conditions must be met:

- correct understanding of the content and form of tasks on resource saving and energy-efficient changes in the company's work, its relations with other entities;

- the adequacy of the tasks of the employee's qualification;

- recognition by the employee of the importance of his contribution to the process of resource saving and energy efficiency growth, achieving the interests of society;

- support for the initiative and evaluation of results [8].

Along with external motivation, it is necessary to influence the internal motivation of employees, because its absence will inhibit any energy-efficient changes in the enterprise.

The corresponding system of motivation employees should be considered as a factor of increasing the efficiency of management, oriented not only 
economically but also environmentally, and at the same time as a system of complex impact on the staff on the basis of increasing the internal motivation of employees, which increases the activity of their activities in the direction of resource-saving actions.

Therefore, when improving the system of staff motivation, it is advisable to take into account the following principles:

- the complexity of the motivational model, which involves the simultaneous use of moral and material, collective and individual incentives;

- differentiation of motivation tools for implementing energy-efficient changes depending on the age, mentality and social status of employees using an individual approach to stimulating different groups of staff;

- flexibility of motivation tools and efficiency of decision-making on incentives, which is manifested in the constant revision of incentive systems under the influence of changes in society and the workforce.

Motivation of energy saving is a structural element of the process of energy efficiency management of a modern enterprise and consists in building a system of incentives for employees to economical and rational use of fuel and energy resources [3].

It should be noted that the current legislation of Ukraine enables to encourage employees to save fuel and energy resources. Material stimulation of labor collectives and individual employees of enterprises for effective use of fuel and energy resources and water is carried out in accordance with the order of the State Committee of Ukraine on energy saving and the Ministry of economy of Ukraine dated 21.06.2000 No. 47/127 "on approval of the Regulations on material stimulation of collectives and individual employees of enterprises, organizations and institutions for saving fuel and energy resources in public production" by awarding. The purpose of the regulation is to strengthen the creative and business activity of employees and managers of enterprises, organizations and institutions of their material interest in reducing the energy intensity of production by rationalizing the use of fuel and energy resources [12].

According to this Provision, material incentives for efficient use of energy resources are provided by awarding employees within the established share of the cost of saved energy resources. The head of the enterprise is granted the right to reduce the size of the award or to deprive it completely for failure to perform tasks to reduce the energy intensity of products, the use of secondary energy resources, for overspending of certain types of fuel or electricity. The basis for material incentives for labor collectives and individual employees of enterprises is the calculation of the cost of saved fuel and energy resources and water, based on the actual specific costs of fuel and energy resources. The calculation is made according the accounting of the consumed fuel and energy resources and water with the use of auxiliary information and data, operational accounting departments and is documented in the economic service of the company, signed by the chief 
electrician, chief accountant, chief economist, state inspector for energy conservation and approved by the Director of the company. Accounting for the use of heat energy is necessary for the analysis and management of energy consumption processes. Effectively adjusted energy accounting allows you to quickly and efficiently analyze its consumption, make the right decisions about measures that will improve the efficiency of energy use. Usually, the amount of the premium Fund is determined as a percentage of the amount of savings of a particular type of energy resources [12]. At the same time, bonus systems must necessarily be cost-effective, purposefully stimulate positive energy-efficient changes with appropriate psychological perception of all aspects of the incentive system by employees.

As mechanisms of incentives for efficient use of energy resources can be distinguished: communication between job performance (qualitative and quantitative) based on energy savings at a certain stage of the production process and labour reward.

One of the means of monitoring the effectiveness of energy-efficient changes implementation at the enterprise can be an energy audit. Achieving noticeable energy savings and adequate perception of energy-efficient changes by employees at the enterprise is possible if the energy management system is implemented.

Energy management is the process of managing all aspects of the company's energy saving activities. The main goal of energy management is to provide the most effective ways to implement the energy-saving strategy of the enterprise at certain stages of its development [4].

The main tool for implementing the mechanism of energy-efficient changes can be attributed to both financial and incentive motivation.

To financial aspects of motivation of employees of the enterprise to energy saving it is possible to carry:

- premiums proportional to the cost of annual stored energy;

- bonuses;

- providing social packages;

- valuable gifts, vacation packages.

The incentive aspects include:

- provision of additional vacation days;

- reduction of the working day with the preservation of wages;

- awarding certificates, commendations, commemorative signs, the use of honor boards and the like.

In addition to motivational tools, the company should also implement a system of penalties, which is based on fines, reduction of bonuses, reduction of additional days off and other areas that do not contradict labor legislation and agreed by the company's management with trade Union committees. However, it 
should be noted that the abuse of negative incentives can lead to the fact that they cease to operate.

It should be noted that according to article 147 of the labor Code for violation of labor discipline, only two penalties can be applied to employees reprimand or dismissal, and it is forbidden to collect fines from wages, but this does not stop many Ukrainian employers. They create a system of remuneration with a constant and variable part, and it is the latter that is the subject of punitive manipulation. Changes in the market economy, legislation, political environment, business models and goals of the company require employees to take a fresh look at the problem, creative, creative approach to decision-making, internal freedom to expand horizons and go beyond the already known methods of work. The system of penalties is based on fear and avoidance, but the fear of punishment is not a guarantee of avoiding mistakes, it rather blocks normal mental activity and leads to a drop in performance [9].

The structural diagram of the process of implementing the motivational mechanism of energy-efficient changes in the enterprise is shown in Fig. 3.

Implementation of the motivational mechanism without monitoring its support at all structural levels of the enterprise can lead to the gradual extinction of insufficiently motivated organizational decisions and insufficient organizational, technical, and production support for implemented energy-saving measures.

For effective implementation of the proposed solutions by all employees involved in the process of the enterprise, there is a need to implement a set of actions aimed at monitoring the existing situation.

As a rule, when applying any motivational theory, quite an important area of consideration the question of correct choice and definition of the guidelines from the standpoint of motivation of energy saving, the implementation of which will contribute to the achievement of the staff assigned to the enterprise goals, defining ways to achieve them, that is the Foundation and implementation of the appropriate set of motivational programs and activities as reactions to the challenges of modernity [1].

The monitoring tools include heat, electric energy, water, waste water meters, temperature, pressure, flow, humidity sensors, and others. Information from the sensors is sent to the computers of the relevant services, where it is processed and stored. 


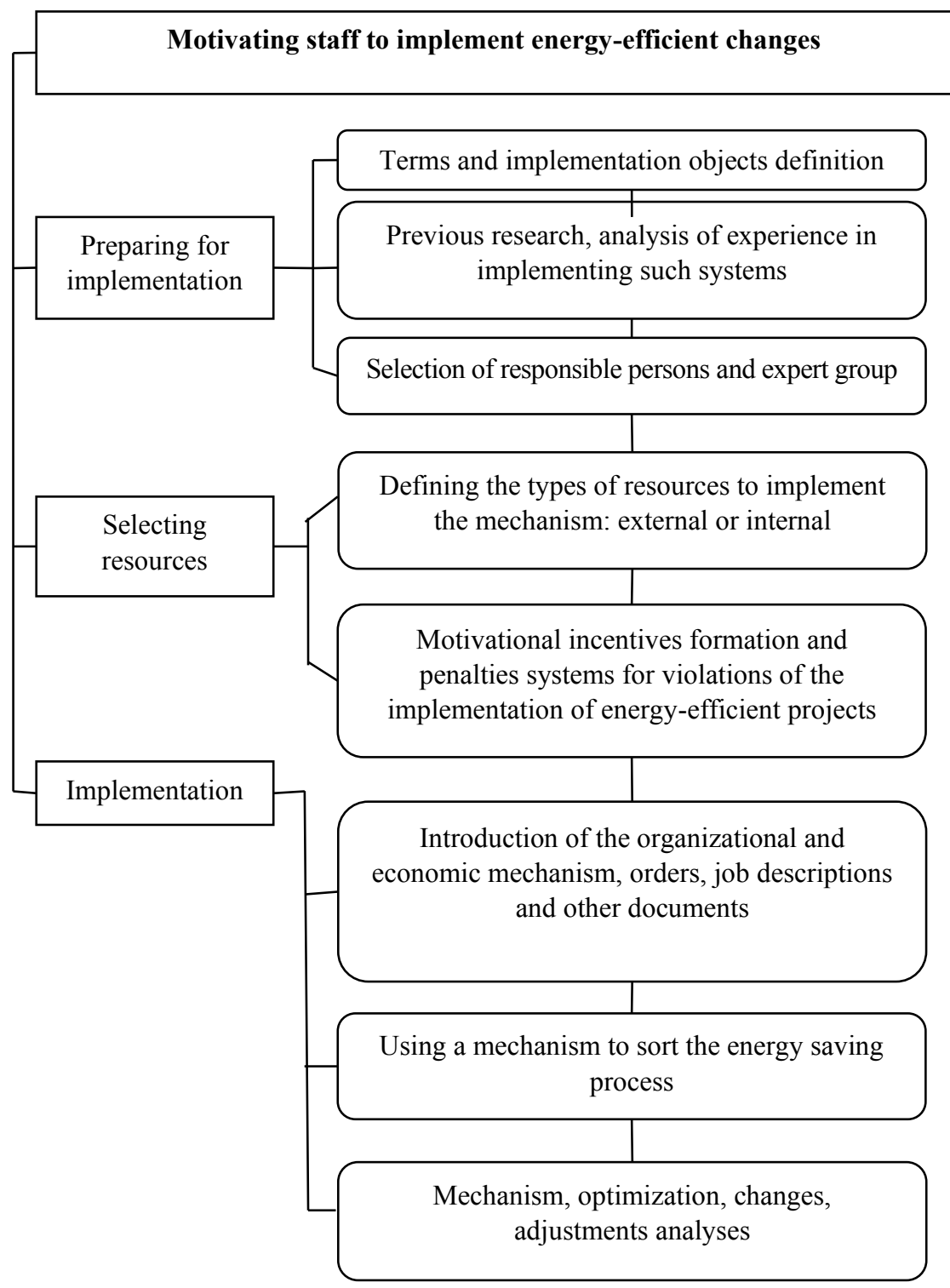

Fig. 3 - Energy-efficient changes motivational mechanism formation process at the enterprise structural diagram 
These proposals provide for changes to the current Regulations on material incentives for the collective and individual employees of enterprises in order to motivate staff to save energy for saving fuel and energy resources.

The purpose of this Provision is to strengthen the creative and business activity of employees and managers of the enterprise, their material interest in reducing the energy intensity of production by rationalizing the use of fuel and energy resources. The funds used by the enterprise for material incentives for saving resources are credited to the gross costs. From the point of view of ensuring economic efficiency, the total amount of funds that can be used to award employees should not exceed $30 \%$ of the cost of saved energy resources. The total amount of saved energy resources at the enterprise or in a particular production unit is determined by the cumulative total over a period of time, the results of which are set variable part of the remuneration. Usually such periods do not exceed 3 or 6 months, which is associated with a negative impact on the motivation of employees to save energy due to the increase in the time between the result and the receipt of material remuneration [12].

It is important to determine the factors that affect the energy efficiency of an industrial enterprise as elements of the environment of its formation (table. 1).

At the stage of adaptation of the enterprise to the new motivational mechanism, certain subsystems require attention and implementation (Fig. 4), allowing to start implementation measures to improve energy efficiency and carry out corrective actions. According to the provided energy efficiency management algorithm, the company will be able to implement the energy saving program and apply it to each service separately.

Energy efficiency management leads to the need for timely identification of problems in the course of work and control of its functioning.

Based on the above, we can offer the following directions for developing a model of motivational mechanism for energy-efficient changes in the enterprise (Fig. 5). As a result of proposed mechanism formation, the company can expect to increase energy efficiency and reduce the cost of production, which in turn can contribute to improving competitiveness and increasing performance.

Competent business management cannot be organized until all levels of the company's management are aware and understand the needs, motivations and incentives of their own employees. Without a well-coordinated team, the labor collective also becomes impossible to carry out economic activities, therefore, the interest of employees is a key condition for the growth of the company's profits [5].

Mechanism formation for motivating staff to save energy is advisable to start with the definition of specific goals and check the technical and economic feasibility of achieving them. 
Table 1 - Industrial enterprises energy efficiency factors

\begin{tabular}{|c|c|}
\hline Responsibility center & Influence factor \\
\hline \multirow[t]{3}{*}{ Human resources } & $\begin{array}{l}\text { Personnel qualification level in the field of energy } \\
\text { saving }\end{array}$ \\
\hline & $\begin{array}{l}\text { Cooperation level with other companies in the field of } \\
\text { experience exchange, participation in energy saving } \\
\text { events }\end{array}$ \\
\hline & $\begin{array}{l}\text { Personal incentive system availability for saving } \\
\text { energy resources (ER) by personnel }\end{array}$ \\
\hline Energy audit & Energy audit system availability \\
\hline \multirow[t]{6}{*}{ Production } & $\begin{array}{l}\text { Energy-saving technologies and equipment } \\
\text { application }\end{array}$ \\
\hline & Degree of secondary use of HER degree \\
\hline & Production technology efficiency level \\
\hline & ER accounting system modernization \\
\hline & Focus on energy-efficient production \\
\hline & ER costs regulation \\
\hline Energy service & $\begin{array}{l}\text { Infrastructure availability for servicing the supply } \\
\text { system at the enterprise ER }\end{array}$ \\
\hline \multirow{6}{*}{$\begin{array}{l}\text { Enterprise interaction } \\
\text { with the external } \\
\text { environment }\end{array}$} & $\begin{array}{l}\text { System availability monitoring legal acts regulating } \\
\text { ER }\end{array}$ \\
\hline & Participation in energy saving programs \\
\hline & State fiscal policy focused on energy saving \\
\hline & $\begin{array}{l}\text { Financial motivation availability for enterprises to } \\
\text { improve energy efficiency }\end{array}$ \\
\hline & Tariff policy of the state in the sphere of ER \\
\hline & Tariff policy of the ER supplier \\
\hline \multirow{2}{*}{$\begin{array}{l}\text { Company financial } \\
\text { state }\end{array}$} & Investment potential in energy efficiency \\
\hline & Financial condition of the company \\
\hline
\end{tabular}

The proposed motivational mechanism for energy-efficient changes involves the analysis of the structure of energy consumption of the enterprise and the search for the most promising areas of energy saving with the involvement of personnel. The presence of a system of motivation in the enterprise is not yet a guarantee of motivation of the staff to certain actions. It will really stimulate employees only if there is a motivational environment formed on the basis of the attitude of the staff to motivational measures.

So, the motivation of energy saving is a structural element of the process in energy efficiency management at a modern enterprise and consists in building a system of incentives for employees to economical and rational use of fuel and energy resources. 
The main tool for implementing the mechanism is motivation based on financial and incentive aspects.

It is proposed to amend the current Regulations on material incentives for the collective and individual employees of enterprises in order to motivate staff to energy saving for saving fuel and energy resources.

Appropriate is the combination of non-material remuneration in the form of social approval and monetary bonuses, which act as a reinforcement in the process of motivating staff; motivation by career and change of functional responsibilities. For those interested in employees professional and career growth, it is appropriate to provide a system of promotion for achievements in the field of energy conservation.

Energy efficiency management leads to the need for timely identification of problems in the course of work and control of its functioning.

As mechanisms of workers stimulation at the enterprise for efficient use of energy resources can be distinguished: communication between job performance (qualitative and quantitative) based on energy savings at a certain stage of the production process and labor remuneration; consolidation of human resources in the enterprise.

As a result of formation of the proposed mechanism, the company can be expected to improve the efficiency and reduce the cost of production, which in turn can improve competitiveness and increase efficiency of economic activities.

Energy-efficient changes motivational mechanism adaptation stage

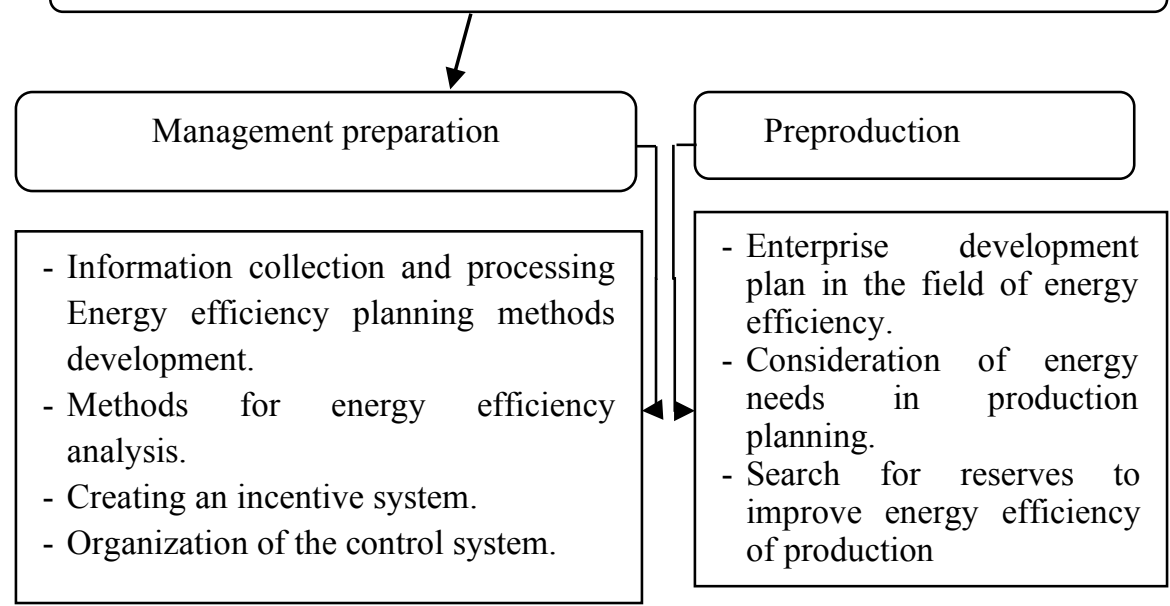

Fig. 4 - Motivation management adaptation directions algorithm for implementing energy-efficient changes in the enterprise 
Economics Energy Efficiency: Problems of Nowadays and of the Future

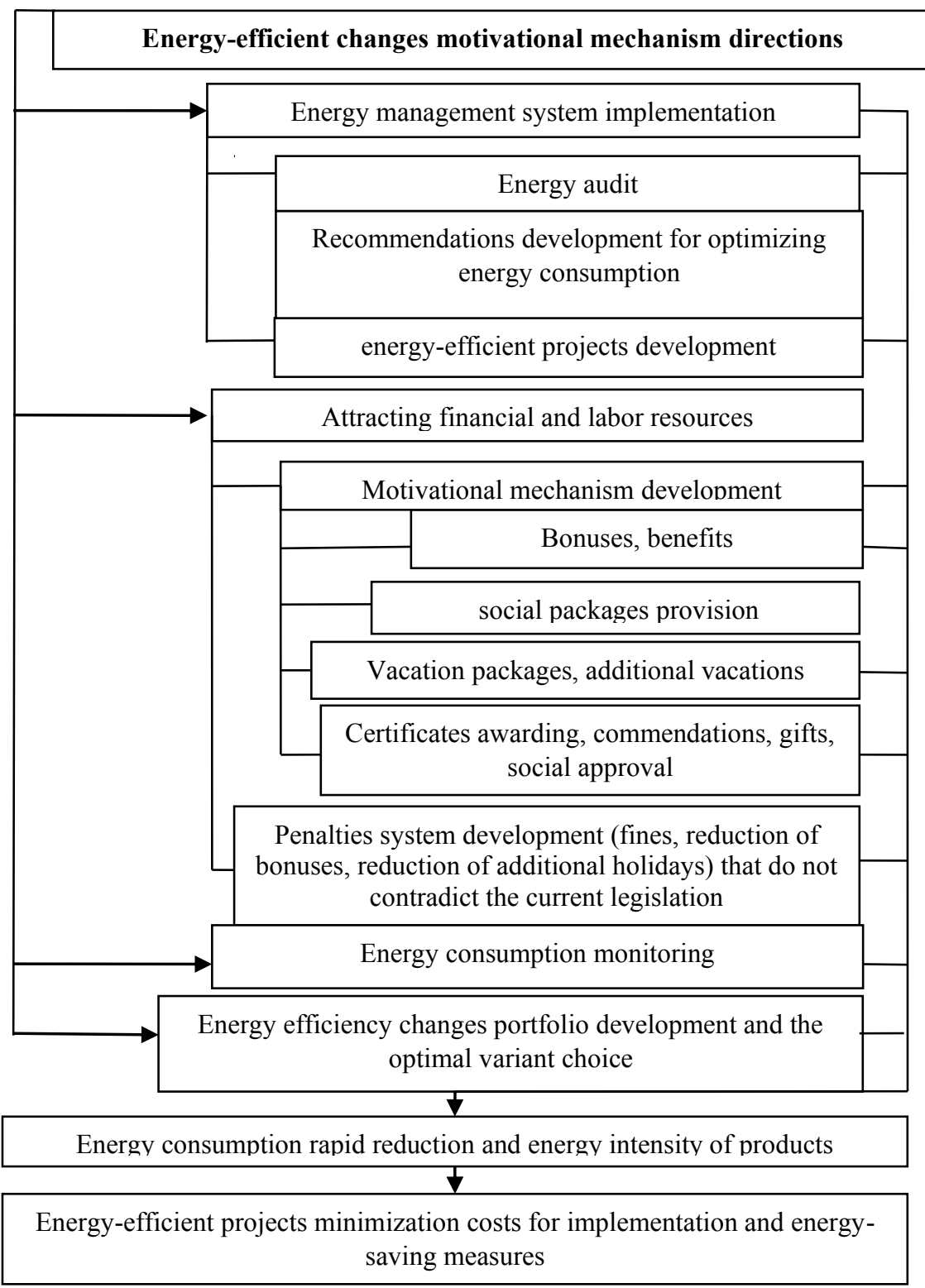

Fig. 5 - Measures to form a motivational mechanism for energy-efficient changes in the enterprise 


\section{References:}

1. Vasiuta, V.B., Ivanytska, S.B. \& Halaida, T.O. (2019). Formation of a motivational mechanism for energy-efficient changes in a construction company // Building Innovations - 2019: zbirnyk naukovykh prats' za materialamy II Mizhnarodnoi ukr.-azerb. konferentsii, 23 - 24 travnia 2019. [collection of scientific papers based on the materials of the II International Ukrainian Academy of Sciences."no. conferences, may 23 - 24, 2019]. - Poltava: PoltNTU. - p 447449 [in Ukrainian].

2. Hrabar, O.I., Klymchuk, M.M. (2017). Management of staff motivation for energy saving in the enterprise: reflexive modification // Visnyk Odeskoho natsionalnoho universytetu. Seriia: Ekonomika. - V. 22, Edition. 7. - p. 82-86 [in Ukrainian].

3. Danilkova, A.Iu. (2016). Management of energy efficiency of industrial enterprises (Ph.D. Thesis). Sciences: spec. 08.00.04 [Electronic resource] / Anastasia Yurievna Danilova; [of Sciences. head of Voynarenko M. P.]; Khmelnitsky national University. - Khmelnitsky. - 221 p. [in Ukrainian].

4. Zalashchuk, L.V. (2018). Energy management as a basis for ensuring energy efficiency of the company's production activities // Infrastruktura rynku. Edition. 17. - p. 138-144. [in Ukrainian].

5. Ivanytska, S.B., Halaida, T.O. \& Diachenko, Yu.O. (2018). Problems of determination and extension of negative influence of personnel demotivation factors on the performance of labor // Ekonomika ta suspilstvo. - №19. - p. 409415. [On line resource]. - Access mode: DOI: https://doi.org/10.32782/25240072/2018-19-62 [in Ukrainian].

6. Klymchuk, M.M. (2017). Theoretical-empirical provisions of the economic and management mechanism of personnel motivation for energy saving at the enterprise // Sotsialno-ekonomichni problemy i derzhava. - Edition. 2. - P. 65-73. [On line resource]. - Access mode: http://nbuv.gov.ua/UJRN/Sepid_2017_2_8 [in Ukrainian].

7. Kotelnykova, Yu.M. (2018). Personnel support in improving the energy efficiency of enterprises [On line resource]. - access mode: http://bses.in.ua/journals/2018/28_1_2018/33.pdf [in Ukrainian].

8. (2016). Motivational mechanisms for dematerializing and energyefficient changes in the national economy: monohrafiia / za zah. red. d.e.n. I.M. Sotnyk. - Sumy. - Universytetska knyha. - 368 p. [in Ukrainian].

9. Staff motivation: why negative incentives don't work [On line resource]. - access mode: https://prohr.rabota.ua/motivatsiya-personalu-chomu-negativnistimuli-ne-pratsyuyut/ [in Ukrainian].

10. Kasianova, N.V. (2017). Implementation of energy saving strategy in industrial enterprises // Efektyvna ekonomika, 2 [On line resource]. - access mode: http://www.economy.nayka.com.ua/?op=1\&z=5916 [in Ukrainian]. 
11. Nakonechna, D.Iu. (2013). Peredumovy stvorennia efektyvnoi systemy upravlinnia enerhooshchadzhenniam na pidpryiemstvi // Efectivna economika, 1 [On line resource]. - Access mode: http://www.economy.nayka.com.ua/?op=1\&z=1731 [in Ukrainian].

12. Regulations on material incentives for collectives and individual employees of enterprises, organizations and institutions for saving fuel and energy resources in public production [On line resource]. - Access mode: http://zakon.nau.ua/doc/?code=z0405-00. [in Ukrainian].

13. Temchenko, H.V. (2012). Methodological support of energy saving motivation at mining and processing enterprises // Ekonomichnyi chasopys- XXI. №9/10. - P. 73-75. 